\title{
Laying a Foundation for Comparing Departmental Structures between Reference and Instructional Services: Analysis of a Nationwide Survey
}

\section{Kristin Johnson and Kathleen Carlisle Fountain}

\begin{abstract}
Public services librarians in academe juggle multiple duties, with reference and instruction being the two most common and visible. A survey of midsized academic libraries measured the departmental relationship between librarians who provide reference services and librarians who provide instruction services. Results indicate that services are generally organized in one department and instruction coordinators are prevalent. Regardless of departmental structure, reference and instruction librarians have similar jobs; they nearly all teach classes and work at the reference desk. Summarization of the subjective commentary reveals underlying satisfaction levels with various organizational arrangements and insight into the pros and cons of maintaining integrated or separate reference and instruction services.
\end{abstract}

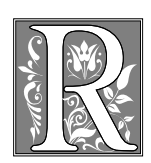

eference work and library instruction are responsibilities common to many academic public service librarians in the twenty-first century. In fact, because job responsibilities so closely overlap, the distinction between reference librarian and instruction librarian is often only one of semantics. Many academic librarians are expected to perform the multiple functions of departmental liaison, collection development specialist, reference desk staff, and classroom teacher, regardless of their title. However, this is a fairly new trend. Although instruction occurred at some level throughout the history of the library profession, librarians increasingly became responsible for reference and instructional duties around the late 1960s and early 1970s when the instruction movement began to be formally organized. ${ }^{1}$ These duties continue to be blended in the library profession today.

In addition, the library profession continues to address instruction and reference together as well as separately in the various professional venues. Job advertisements often highlight the need for librarians to both teach classes and work at a reference desk. With the exception of Research Strategies, public services professional journals maintain a "reference" focus in their titles (Reference Services Review, The Reference Librarian, Reference and

Kristin Johnson is an Information Literacy/Instruction Librarian and Kathleen Carlisle Fountain is the Political Science and Social Work Librarian in the Meriam Library at California State University-Chico; e-mail:kajohnson@csuchico.edu and kfountain@csuchico.edu, respectively. 
User Services Quarterly) whereas instruction articles comprise the majority of their content. ${ }^{2}$ Conversely, professional electronic mailing lists make a clear distinction between reference and instruction (DIG-REF-digital reference, LIBREF-Lgeneral library reference, FYE-LIBfreshman orientation and library instruction, BI-L-bibliographic instruction). In addition, instruction-focused conferences, such as LOEX and LOEX-of-theWest, occur in an independent forum whereas reference programs are presented only at larger "umbrella" forums such as ALA conferences. Reference and instruction librarians also can find useful, separate professional organizational "homes" within the ALA network. ${ }^{3}$ Examples of these groups include the Library Instruction Round Table or Reference and User Services Association. These channels of communication for librarians demonstrate that reference and instruction librarians can have both distinctive and comparable interests-work that cannot be easily regarded as a finite set of duties and responsibilities.

During the past decade, the information literacy movement has increased in prominence as college campuses have shifted to a student-centered learning model with accountability and assessment serving as buzzwords for effectiveness. For public services librarians in academia, this movement may have focused attention toward classroom instruction and campus outreach and away from the traditional reference desk instruction. Because instruction and information literacy efforts are increasingly visible elements of library services in academe, does this mean that the duties of reference and instruction librarians are more clearly separated? If so, have instruction departments been created independently from reference departments as a result? One might consider studying library department structures to answer these questions. After all, organizational structure plays a key role in laying the foundation for implementing best practices for reference and instruction services.

\section{Survey Rationale and Literature Review}

This research arose initially out of a need for information to make an organizational decision within the Meriam Library at the authors' university. Adiscussion centered on whether to combine reference and instruction services, which at the time of this writing were organizationally separate. In the Meriam Library, instruction serves as an essential facet of the library's mission. The goal of maintaining an autonomous instruction program is to foster innovative outreach efforts, expand the reach of course-related instruction, and participate in the three-credit, general education Introduction to University Life course by providing a strong information literacy component. However, as the instruction program evolved from its inception twenty years ago, reference librarians became increasingly active classroom teachers, and the distinction between the normal duties of the instruction and reference librarians blurred.

To facilitate the decision-making process, a literature search was conducted. The literature is replete with articles discussing pedagogical techniques for instruction or best practices for reference desk service, but little was found on the relationship of these two services in terms of departmental structure. In fact, out of an entire issue of a 1984 Reference Librarian devoted to the theme of library instruction and reference services, only one short article discussed the administration of a bibliographic instruction (BI) program. In this theoretical article, Maureen Pastine discussed the pros and cons of managing an instruction program within the reference department. She concluded with a recommendation, stating:

[The] shift in bibliographic instruction responsibilities and activities calls for a re-examination of how bibliographic instruction programs should be administered, and in my view strengthens the position of bibliographic instruction as a separate service, equivalent to other library- 
wide priorities. I anticipate that in the future there will be no question that a bibliographic instruction program should be administered outside of the confines of the reference department, or public services division. ${ }^{4}$

Another article discussed the reference/instruction departmental relationship from a more practical standpoint. It described a reorganization that took place in the Colorado State University library reference department, which moved from "responsibilities by subject" to "division by function" and thus created a separate instruction group. ${ }^{5}$

Recent library literature on reengineering academic library public services focused on bigger administrative issues, such as combining library reference with campus computing services. For example, applying a corporate administrative model to library services is the theme of an insightful 1994 article that concentrated on user services to the library patron. ${ }^{6}$ However, what this and other articles lack is a practical administrative approach to the realities of the duties assigned to reference and instruction librarians. It appears, then, that an important aspect regarding the link between reference and instruction has heretofore been overlooked in the professional literature: the departmental or organizational relationship between these two services. Because the library profession has had no documented models or benchmarks regarding the relationship between reference and instruction departmental organization, it seems, then, that the administrators of these services have been acting either in isolation or within informal networks of communication.

One recent article addressed some of the same concerns as this article. In analyzing job advertisements in selected years over a twenty-year period, Beverly P. Lynch and Kimberley Robles Smith found that all reference librarian announcements in 1993 and 1998 required the successful applicant to teach instruction courses. However, they found no in- struction librarian position announcements. ${ }^{7}$ Lynch and Smith hoped to evaluate the changes in administrative structure with their methodology but offered no conclusive results. However, they did point to an increasing reliance on team management or, at the very least, team decision-making procedures.

These findings are consistent with the tone of many articles focusing on the changing nature of reference work. The assumption found in the literature is that reference librarians universally accepted the role of instruction as it developed in the academic library, despite its challenges. ${ }^{8}$ In 1984, William Miller cited instruction as one of the significant new additions to the roster of reference librarian duties and a cause of consternation. ${ }^{9}$ Audrey D. Moore's 1996 article described library instruction as one of three enduring reference service categories, the other two being informational services and reader's advisory services. ${ }^{10}$

In the early 1990s, librarians debated how reference services ought to incorporate instruction. Some librarians explicitly rejected formalized instruction in favor of offering instruction services with the reference interaction. ${ }^{11}$ The opposite opinion asserted that the advent of technology and library instruction should mean the end of the reference desk service. ${ }^{12}$ Most, however, seemed to regard instruction as a natural extension of the work of reference librarians and reference departments. Because of this theoretical conflict, some administrators encouraged the creation of instruction services organized separately from the reference departments. David F. Kohl remarked on his experiences that "instruction programs can not adequately or fully develop as 'little sisters' [of reference] . . .they need a room of their own."13 Therefore, questions arise concerning the prevalence of separation and what it means for the responsibilities of the librarians.

The literature, then, did not offer information on the number of separate reference and instruction departments, ra- 
tionales for their organization, and the subjective reaction of librarians regarding the pros and cons of various departmental structures. Data did not surface to help determine whether the departmental structure at the Meriam Library was typical or an aberration. Instead, it posed additional questions that could not be answered by existing research. The dearth in the literature led to the decision to conduct a survey to gather the needed information. The results were expected to be useful in the decision-making process to possibly revise the Meriam Library's reference and instruction departmental structure. After further consideration, the authors realized that results of such a survey also would be useful for the academic library community at large.

\section{Research Expectations/Hypothesis}

Because of increased emphasis on information literacy nationwide, the authors surmised that a recent library trend would be the organization of reference and instruction services into distinct departments in an effort to place greater emphasis on campuswide information literacy efforts. Based on the argument against formalized instruction, it also was hypothesized that within institutions where reference librarians rarely provide bibliographic instruction because of an expressed dislike of classroom teaching, reference and instruction would be more often organized into two separate departments. In those academic libraries where reference and instruction librarians had overlapping duties (i.e., reference librarians teach and instruction librarians work at the reference desk), reference and instruction services were expected to be combined in the same department. In addition to numeric data, the authors expected to gain insightful subjective commentary from the survey respondents that might aid them in facilitating discussions regarding change in their own library.

\section{Methodology}

Proceeding on the assumption that a university's size and makeup would help determine the character of the library and reference/instruction program, a discrete survey population was identified so as to compare the authors' institution to similar universities. Meriam Library is part of a public, comprehensive state university system and has a full-time equivalent (FTE) student enrollment of approximately 14,500. A master's degree is the highest degree offered. Therefore, survey candidates consisted of public, four-yearplus universities with an FTE student population between 10,000 and 19,000. This range was selected in order to broaden the survey population to institutions within a range 4,500 greater or lesser than the authors' institution. Institutions smaller than 10,000 FTEs were not included because they likely would not have enough staff to justify maintaining separate departments. Schools with student populations larger than 19,000 were not surveyed because they may be more likely to have separate departments due to budgetary advantages, larger student populations, or a multilibrary campus. Private and independent institutions were not included due to the likelihood of incomparable funding structures that stand in contrast to those of state schools.

Using the College Source online database published by the Career Guidance Foundation and the criteria of public master's- and doctorate-degree granting institutions between the 10,000 and 19,000 FTE enrollment levels, 110 institutions were identified. Three institutions were later eliminated from the survey when their enrollment figures were determined to be well above or below the intended range, leaving a total survey population of 107. Of those, seventy-six valid surveys were returned for a response rate of 71 percent. Twenty-eight of the responding institutions offered a master's degree as their highest degree, and forty-eight offered doctorates.

Searching library Web pages helped to identify either the lead instruction librarian or head of reference at each institution. If neither could be identified, a public services librarian was selected. These 
individuals were targeted as respondents to the authors' e-mail survey, which was conducted during May and June 2001. The e-mail consisted of a cover letter followed by the survey questions, all contained in the body of the e-mail and not as an attachment. Approximately two weeks after the initial e-mail, follow-up e-mails were sent only to those librarians that had not yet responded. Librarians with titles such as instruction coordinator or instruction librarian comprised 59 percent $(n=45)$ of the respondents. Twelve reference department heads and twelve heads of combined reference and instruction departments contributed 32 percent of the responses. The remaining 9 percent were submitted by other librarians when an instruction librarian or department head could not be identified. Overall, librarians officially titled instruction librarian provided the majority of the subjective information in the study.

The survey consisted of seventeen questions, fourteen objective and three subjective, focused primarily on the organizational structure between reference and instruction and the activities performed by reference and instruction librarians in each library. Questions included:

- Approximately how many students do your bibliographic instruction efforts reach in each twelve-month period?

- How are your reference and instruction services organized?

- Have your instruction services merged with, or separated from, the reference department within the past five years?

- In general, do you believe your organization is satisfied with the relationship between BI and reference?

- What do you perceive as being the benefits and drawbacks of having separate reference and instruction departments?

To keep the survey concise and manageable, it was decided not to include questions on the following subjects: size of the library, whether the campus had multiple libraries, whether any credit- based library research courses were offered, whether there was a campuswide information literacy competency requirement, details regarding institutional funding, or time-on-task questions relating to the librarians' job responsibilities.

\section{Survey Definitions}

Within the body of the cover letter and the survey itself, several terms called for definition. It was explained that "library instruction programs" referred to programs known by names such as "user instruction," "user orientation," "bibliographic instruction," "user education," "bibliographic education," or any combination of the above. Although "reference department" was believed to be a static and widely understandable term, it was nonetheless defined as the department in the library that oversees services at the physical reference or research desk and the print and electronic reference collections.

\section{Only one library maintains "biblio- graphic" to describe the instruction department, but it is clearly out of vogue.}

For the purposes of the survey, "bibliographic instruction" was defined as any type of library user education classes or tours that take place within the library or in campus classrooms but are outside credit-based library research courses. These instruction sessions are sometimes referred to as one-shot sessions but also include two, three, or more sessions, as long as they are not offered for credit. The authors' institution does not offer a creditbased library research course. Such courses vary dramatically from institution to institution, and for the purposes of this particular survey, including them as part of library instruction would not render comparable results. ${ }^{14}$ Library tours are considered part of library instruction and counted toward the yearly number of classes. Reference desk encounters and independent office consultations, however, are not included in this definition. 
Finally, respondents were asked to report on the number of patrons receiving library instruction in a twelve-month period. For "twelve-month period," the respondents could choose to report their fiscal, academic, or calendar year class totals. The total number of classes, including any summer session or special sessions held on each campus outside the traditional quarter or semester, was more important for this survey than the chosen reporting period.

\section{Results}

\section{Norms in Departmental Structure}

Overall, the majority of respondents reported that reference and instruction services existed in one department $(79 \%, n$ $=60$ ), which was expected based on the literature assumptions. Eight libraries $(10.5 \%)$ maintained separate reference and instruction departments, and an equal number stated that their structure took on some other form. "Other" arrangements included organizing instruction through a librarywide committee, a lack of any formally organized departments throughout the library, and a librarywide instruction effort without an organizational home (table 1).

To document possible changes in the organizational relationship between reference and instruction, a series of questions was asked to determine the stability of departmental structure within the previous five years. The majority of respondents stated that their library retained the same organizational structure as five years ago $(73.7 \%, \mathrm{n}=56)$. Twenty $(26.4 \%)$ libraries reported changing their organizational structure; of these, ten (13.2\%) reported that they had separated the two services and an equal number reported merging them (table 1). Those respondents who

\begin{tabular}{|c|c|}
\hline \multicolumn{2}{|c|}{$\begin{array}{c}\text { TABLE } 1 \\
\text { Characteristics of Department Structure }\end{array}$} \\
\hline Reference and Instruction Organizational Structure & N (\%) \\
\hline Combined in one department & $60(79)$ \\
\hline Separate departments & $8(10.5)$ \\
\hline Other structure & $8(10.5)$ \\
\hline Total & 76 \\
\hline Changes in Departmental Structure in the Past Five Years & N $(\%)$ \\
\hline Retained same organization & $56(73.7)$ \\
\hline Separated reference and instruction & $10(13.2)$ \\
\hline Combined reference and instruction & $10(13.2)$ \\
\hline Total & 76 \\
\hline Library Has an Instruction Coordinator & N (\%) \\
\hline Yes & $69(90.8)$ \\
\hline No & $6 \quad(7.9)$ \\
\hline Total & 75 \\
\hline Supervisor of Instruction Coordinator & N (\%) \\
\hline Head of public services & $14(18.4)$ \\
\hline Library director & $11(14.5)$ \\
\hline Head of reference & $28 \quad(36.8)$ \\
\hline Other & $15 \quad(19.7)$ \\
\hline Total & 68 \\
\hline
\end{tabular}


stated their libraries had maintained the same organizational structure for five or more years were asked if they had considered, or were considering, any organizational changes. Very few answered yes, with five $(9.1 \%)$ considering separating reference and instruction and three (5.5\%) considering integration.

\section{Instruction Coordinators Are Prevalent}

Regardless of departmental structure, libraries typically have one librarian officially designated as coordinator of library instructional efforts $(90.8 \%, \mathrm{n}=69)$. A follow-up question asked to whom the instruction coordinator reported. The responses to this question were more varied than those to previous questions. The highest percentage $(36.8 \%, \mathrm{n}=28)$ responded as reporting to the head of reference. However, 18.4 percent $(n=14)$ reported to the head of public services, 14.5 percent $(n=11)$ reported to the library director, and 19.7 percent $(n=15)$ reported to "other" (table 1). Those indicating "other" either reported to multiple supervisors or their supervisor's title did not appear as a survey option (i.e., associate university librarian or associate dean). The variability of these data is, in part, a result of the semantics of job titles. Numerous titles express the same job responsibilities but are often difficult to reconcile with a list of survey options. According to these lines of responsibility, the authors surmised that these instruction coordinators were generally the head of the instruction program, the head of the reference department, or a designated librarian within the reference department.

\section{Departmental Identity in a Name: "Reference" Is the Norm}

By and large, libraries continue to use the label "reference" to describe the unit that oversees the reference desk $(n=34)$. Most of the libraries that used this term called their departments Reference Department, but others used a variation such as Reference Unit or Reference Services. Combined departments that house both instruction and reference functions have the most variety in their titles, ranging from Reference and Instruction Services to Instructional and Interpretive Services. Other phrases that characterize the instructional element of these departments are "user education," "information services," "research services," "reader services," and "public services."

Those surveyed consistently replied that reference and instruction librarians serve the same purpose, which is to teach either an individual or a classroom of students how to use library resources.

The autonomous instruction departments nearly all use the phrase "library instruction" to describe the responsibility of their units. Only one library maintains "bibliographic" to describe the instruction department, but it is clearly out of vogue. As this article suggests, the academic public service library profession seems to be afflicted with an identity crisis. "Reference" and "library instruction" may evolve into new names as the participants, the activities, and the organizations change.

\section{We Do It All! Data Common to All Libraries}

Along with questions about departmental structure, several of the survey questions centered on basic library instruction program activities, regardless of departmental structure. Four pieces of data clearly document trends common to all responding institutions:

1. One hundred percent of the respondents reported that BI was provided to their campus population.

2. All librarians designated "reference librarian" participated in library instruction efforts.

3. Nearly all $(93 \%, n=73)$ "reference librarians" were actively encouraged to teach instruction sessions.

4. Most $(82 \%, n=62)$ "instruction librarians" provided service at the reference desk.

These trends reflect the nature of the instruction program at the authors' li- 
TABLE 2

Reference and Instruction Organizational Structure by Variable

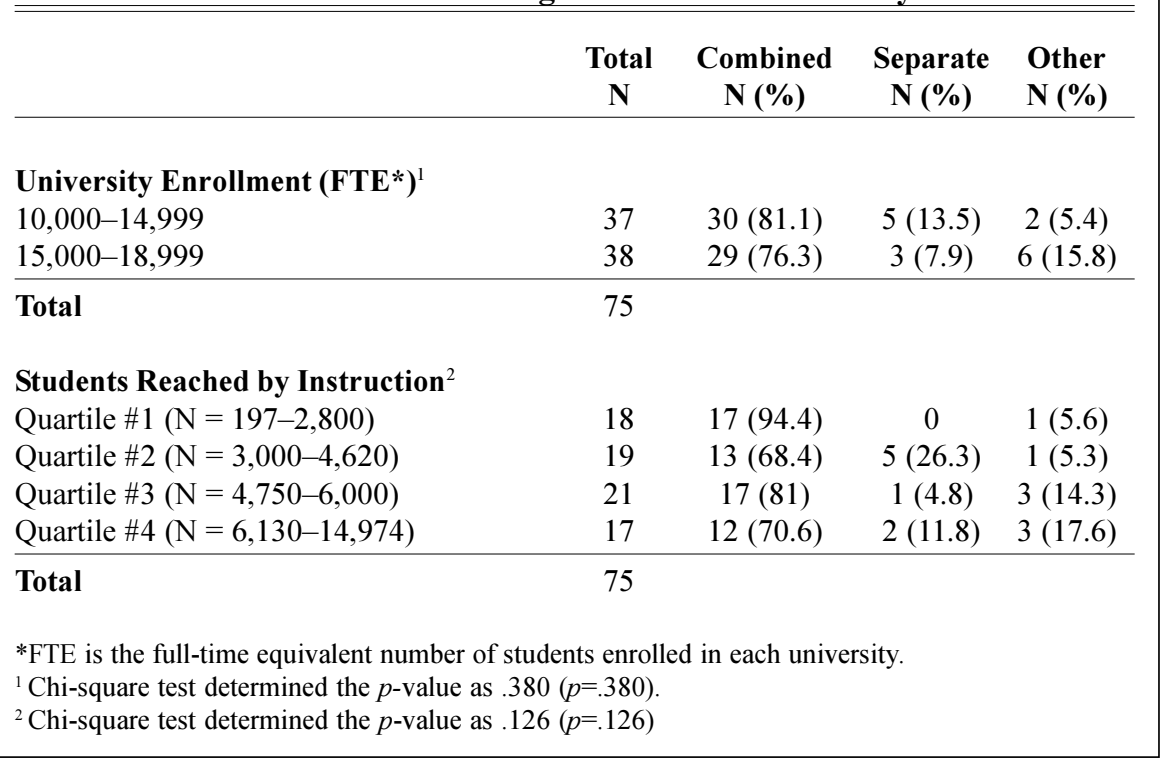

brary, as all public service librarians play an active role in both reference and instruction efforts.

\section{How Many Students Do We Reach?}

The instruction statistics of these libraries showed a wide variety in numbers of students taught in a single year, ranging from 270 to 14,974. Although the survey data suggested that as the student population increased, the number of students reached through BI also increased, the chisquare test did not establish a significant relationship. In a 1996 study, Marybeth Charters found that doctorate-granting institutions reach more students than institutions offering only master's degrees. Again, this suggested a relationship, but not one that was statistically significant. ${ }^{15}$

\section{Cause and Effect: Why Separate Instruction Programs?}

Although the main purpose of this survey was to gain general, enumerative data regarding departmental structures, the authors were curious to know whether any obvious factors influenced libraries to maintain separate reference and instruction departments. The survey showed that the norm was to combine services into one department, with only sixteen of seventy-six libraries having structures other than combined. Of the questions in the survey, two contained information that could possibly have a causal relationship to departmental structure: size of institution (FTEs) and number of students reached through instructional efforts in a twelve-month period.

The authors ran a chi-square analysis, using quartiles for students reached and dividing FTE enrollments into two ranges: 10,000 to 14,999 and 15,000 to 18,999 . The authors' expectations were that institutional size might impact departmental structure, with the larger institutions generating a greater demand for services. Thus, the departments would be separate in larger universities. In addition, there was an assumption that perhaps more students would be reached through instruction efforts at institutions with separate departments because those universities emphasized the importance of instruction with the independent department. However, there is no evidence to support this assumption. The chisquare analysis showed no significant 
causal relationship between departmental structure and university size or number of students (table 2). Nor did any other tests show correlations that would predict the composition of an instruction program of a hypothetical library.

Although the objective results of this survey cannot measure what causes departments to remain combined or separate or to measure the service effectiveness of these arrangement, they do provide an interesting look at the state of instruction programs in midsized universities across the nation. The authors expected that the subjective commentary of the respondents might offer insight into the rationale for various departmental arrangements.

\section{Subjective Commentary: Departmental Satisfaction}

The survey respondents were asked: In general, do you believe your organization is satisfied with the relationship between $\mathrm{BI}$ and reference? Regardless of the structure of the reference and instruction departments, an overwhelming majority of respondents $(97.3 \%, \mathrm{n}=71)$ reported that their libraries, as a whole, were satisfied with their current organization. Two $(2.7 \%)$ respondents expressed dissatisfaction with a combined structure. All eight respondents in separate instruction programs were satisfied with the arrangement.

Explanations for the combined departments' satisfaction centered on three common themes:

1. Their libraries did not employ enough librarians to justify departmental separation.

2. Subject librarians in the reference department are responsible for courserelated instruction in assigned areas

3. Most important, teaching happens at the reference desk as well as the classroom.

Those surveyed consistently replied that reference and instruction librarians serve the same purpose, which is to teach either an individual or a classroom of students how to use library resources. This sentiment found its way into every section of the survey responses. As one librarian remarked, "We consider reference and [bibliographic instruction] twin approaches to the same educational objective."

The respondents who headed up separate instruction departments expressed universal satisfaction with having an autonomous department. They cited the opportunity to focus on instructional goals, missions, standards, and programs as their reasons. "Having someone that spends more time creating the vision, planning, and assessment for [bibliographic instruction] has paid off ... we now have information literacy competency requirement[s] for all students," reported one instruction coordinator.

\section{Subjective Commentary: The Pros and Cons of Maintaining Separate Departments}

Finally, subjective comments were solicited from the respondents via two questions:

1. What do you consider to be the benefits of having a BI program separate from the reference department?

2. What do you consider to be the drawbacks of having a BI program separate from the reference department?

Fifty-two of the survey participants responded to the first question, and fiftyseven responded to the second. The responses were varied, and it became clear to the surveyors that some respondents interpreted the questions as referring to a hypothetical situation (which was the researchers' intention) and others interpreted them to refer specifically to their library. Obviously, those in independent instruction programs could respond to their reality of separate departments. Consistent interpretation of the question may have led to more theoretical responses, but each comment belies the assumptions of the respondents regardless.

The most frequent-and perhaps the most surprising-commentary gleaned from these questions centered on perspectives regarding the teaching continuum 
from the reference desk to the classroom. When asked to comment on the drawbacks of maintaining separate departments, many of the responses implied an assumption that this would result in a complete separation of responsibilities, with reference librarians only staffing the reference desk and instruction librarians only teaching classes. The consequence of this arrangement, as seen by the survey respondents, was that it would manifest ignorance about either classes or reference questions. Because most of the librarians responding to the survey called their respective "reference departments" home, a majority of the comments criticized the potential of separate instruction librarians to "lose touch" with students asking specific questions at the desk.

Another drawback cited by the librarians uncovered a more pragmatic concern. Chiefly, respondents expressed distress that separate departments would create an artificial distinction between two closely related functions. They foresaw increasing communication problems and feelings of exclusion resulting from the organizational distance. In short, they believed it could lead to "fragmentation of purpose and competition over scarce resources." At least one library administration article foreshadowed these concerns. In 1984, Pastine wrote of the friction between reference and other departments due to instruction-related work discrepancies. ${ }^{16}$

When asked about the benefits of a separate instruction program, however, many respondents (including those with combined departments) lauded the idea, saying they perceived one benefit to be extra time to devote to instructional purposes. They saw such an arrangement as enabling the instruction librarians to focus on particular instructional programs. By maintaining a separate departmental presence, they could gain a campuswide visibility not normally given to a program of a reference department. One respondent, an instruction librarian in a library with an independent instruction department, reported, "this allowed us to be very proactive and build a strong program. It spoke to the campus that the library felt that instruction was worthy of 'independent' status."

"Juggling" reference and instruction commitments surfaced as common complaints of the integrated department, and responding librarians reported they could see the attraction of a more simplified set of responsibilities. One librarian exclaimed, "It's hard to do it all!" As explained earlier, this survey did not address time-on-task questions relating to librarians' job responsibilities. However, a recent article analyzing position announcements showed that instruction and collection development are becoming increasingly common elements of a reference librarian's job. These "combination" jobs demonstrated that libraries shifted the same responsibilities to a smaller number of people as budget cuts required. ${ }^{17}$ Although outside the scope of this research, further investigation into the relationship between responsibilities and job satisfaction is warranted in light of the obvious time constraints faced by many librarians. Credit-based library classes are an additional element to study because, as one survey respondent remarked, "the same core people do all of these [reference] and instruction activities, and a lot of stress and strain does come from adding those credit classes."18

\section{Conclusion and Recommendations}

In a 2000 article, Hannelore B. Rader recognized the need for reference librarians to adapt to the new environment of user education by preparing to provide both reference and instructional services. She stated that developing an aptitude for instruction is not just recommended but, rather, it is a tool for "effective professional survival."19 This research found that at midsized public universities, most libraries already incorporate instruction functions into one centralized department aligned with reference services. In addition, one librarian is typically assigned the task of coordinating the instruction efforts, which could include defining the 
mission and goals of outreach programs. The majority of the librarians justified combining these two highly visible elements of public service into one unit because they treated both responsibilities as teaching.

As one might expect, respondents cited the lack of sufficient staff as one of the most practical reasons for maintaining combined departments. A study of job announcements has demonstrated the shrinking number of library personnel and verifies the respondents' rationales for department integration..$^{20}$ Although not the norm, some respondents did report that in their library, separate departments were formed when library management considered classroom instruction a high priority, provided there were sufficient librarians to effectively staff an instruction department.

Although reference librarians may have initially resisted classroom instruction, their role in information literacy efforts evolved with the introduction of teaching in university libraries and is now a regular part of their work. According to this survey, 100 percent of reference librarians teach library instruction sessions. Because they are now expected to teach, it is understandable why instruction research and discussion fill the pages of many traditional reference journals.

Although the survey did not specifically address each library's institutional culture, it did draw on personal narrative to conclude common experiences. The survey comments mirrored sentiments at the authors' institution by showing that the organizational relationship between reference and instruction can dictate the quality of the personnel relationships. Some librarians clearly preferred reference and instruction to be organizationally combined, and they feared organizational distance from an artificial separation. Respondents suggested that combining departments prevents feelings of isolation and fosters common goals in public services. Institutional politics and individual experience can determine the validity of these fears and shape the suc- cess of the organization whether or not reference and instruction share the same departments.

Erasing "organizational boundaries" by instituting an instruction task force could provide a workable alternative to librarians who fear departmental conflict arising from separation. The library at Rice University reengineered its management to create a more flexible structure. By blending responsibilities and creating specialized teams on an as-needed basis, librarians cooperate on projects with other interested librarians instead of only those in their departments. ${ }^{21}$

Other libraries may benefit from the construction of a formal policy for offering instructional services. Such a formalized framework better defines the scope of the program, those responsible for teaching, and the expectation of service to the university. Existing guidelines could help reference departments create reference services policies, including those for user education. ${ }^{22}$ The guidelines prompt libraries to consider their current services, suggest solutions to local problems, and plan for the future of instruction programs.

Many respondents reported that instruction was not confined to any specific department in their libraries because librarians operate as academic liaisons and are considered subject specialists. These librarians provided all course-related instruction for assigned academic programs. Although none of the survey comments suggested this, the authors question who would teach classes if a librarian refused or was otherwise unable to provide library instruction. Service guidelines provide the opportunity to construct lines of authority for an instruction coordinator and dictate who must fill in for the nonteaching academic liaisons.

In the end, each library is unique and has needs that must be addressed individually. The authors recognize variance throughout academe and that additional factors (including departmental structure) must be taken into consideration when organizing reference and instruction services. However, the subjective and objec- 
tive data collected from this survey lead the authors toward recommending combined reference and instruction departments. Because the mission of both reference and library instruction is overall student education through teaching, and because classroom teaching has become a predominant duty of most "reference" librarians, the combined department could facilitate an efficient and effective management of these services. Reflecting current advice in the business word, administrators of these services are encouraged to solicit input from their librarians and to engage in some form of participatory management. ${ }^{23}$ The librarians' view of the relationship between reference and instruction will offer insight into their compatibility, which can lead to a mutually agreeable organizational structure.

\section{Notes}

1. For brief overviews of the instruction movement, see: Hannelore B. Rader, "The Learning Environment -Then, Now and Later: 30 Years of Teaching Information Skills," Reference Services Review 27, no. 3 (1999): 219-24; Mary J. Du Mont and Barbara F. Schloman, "The Evolution and Reaffirmation of a Library Orientation Program in an Academic Research Library," Reference Services Review 23, no. 1 (1995): 85-93.

2. Details on the expansion of library instruction as a topic in the professional literature can be found in Rader, "A Silver Anniversary: 25 Years of Reviewing the Literature Related to User Instruction," Reference Services Review 28, no. 3 (2000): 290-96. A brief summary can be found in Ron Blazek, "The Administrative Climate for Bibliographic Instruction in Large Academic Libraries," Reference Librarian 10 (spring/summer 1984): 161-62.

3. Rader, "The Learning Environment," 222.

4. Maureen Pastine, "Library Instruction and Reference Service: Administration of a Bibliographic Instruction Program in the Academic Library," Reference Librarian 10 (spring/summer 1984): 188.

5. Teresa Y. Neely et al., "Instruction and Outreach at Colorado State University Libraries," Reference Librarian 67/68 (1999): 273-87.

6. Beth J. Shapiro and Kevin Brook Long, "Just Say Yes: Reengineering Library User Services for the $21^{\text {st }}$ Century," Journal of Academic Librarianship 2 (Nov. 1994): 285-90.

7. Beverly P. Lynch and Kimberley Robles Smith, "The Changing Nature of Work in Academic Libraries," College \& Research Libraries 62 (Sept. 2001): 407-20.

8. Examples of this perspective can be seen in the following articles: Bill Katz, "Bibliographical Instruction," in Introduction to Reference Work, vol. II: Reference Services and Reference Processes. $7^{\text {th }}$ edition (New York: McGraw-Hill, 1997), 223-36; James Rettig, “Future Reference-'Sired by a Hurricane, Dam'd by an Earthquake,'" Reference Librarian 54 (1996): 75-94.

9. William Miller, "What's Wrong with Reference: Coping with Success and Failure at the Reference Desk," American Libraries 15 (May 1984): 303-6, 321-22.

10. Audrey D. Moore, "Reference Librarianship: 'It was the Best of Times, it was...,'" Reference Librarian 54 (1996): 3-10.

11. Katz, "Bibliographical Instruction."

12. Keith Ewing and Robert Hauptman, "Is Traditional Reference Service Obsolete?" Journal of Academic Librarianship 21 (Jan. 1995): 3-6. 426.

13. David F. Kohl, “As Time Goes by... Revisiting Fundamentals," Library Trends 44 (fall 1995):

14. Future research could expand on this survey by comparing departmental structures among institutions offering credit-based library courses versus those that do not.

15. Marybeth Charters, "The Extent of Bibliographic Instruction in Academic Libraries: A Preliminary Examination," Research Strategies 16, no.2 (1998): 147-52. Unfortunately, her conclusions are based on only twenty-six responses, so they cannot be assumed conclusive.

16. Pastine, "Library Instruction and Reference Service."

17. Lynch and Smith, "The Changing Nature of Work in Academic Libraries."

18. The additional workload placed on the librarian from teaching a credit-based course is discussed in Kimberley Donnelly, "Reflection on What Happens When Librarians Become Teachers," Computers in Libraries 20 (Mar. 2000): 46-49.

19. Rader, "Information Literacy in the Reference Environment: Preparing for the Future," Reference Librarian 71 (2000): 25-33.

20. Lynch and Smith, "The Changing Nature of Work in Academic Libraries."

21. In the private sector, reengineering is commonly associated with layoffs. This article made 


\section{Laying a Foundation 287}

no indication of eliminating staff. Shapiro and Long, "Just Say Yes."

22. "Information Services Policy Manual: An Outline," RQ, 34 (winter 1994): 165-72. These guidelines were drafted by the Management of Reference Services Committee of the Reference and Adult Users Services Division of the ALA.

23. Steve Gibbons, "Business Experts Ponder the Past, Present, and Future," Journal for Quality and Participation 22 (Nov./Dec. 1999): 18-23. 